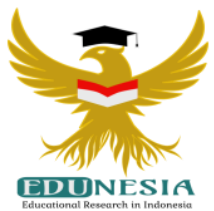

\title{
The Influence of Student Characteristics, Design Learning Features, and Learning Outcomes on Blended Learning Effectiveness (Case study: Higher Education in Indonesia)
}

\author{
Aditya Permadi1; Bayu R Aditya ${ }^{2}$ \\ ${ }^{1}$ Basic Education, STKIP Subang, Indonesia \\ ${ }^{2}$ School of Applied Science, Telkom University, Indonesia \\ ${ }^{1}$ Corresponding Email: aditya.permadi@outlook.com, Phone Number : 0811 xxxx xxxx
}

Article History:

Received: Dec 14, 2020

Revised: Dec 24, 2020

Accepted: Dec 25, 2020

Published: Jan 01, 2021

Keywords:

Blended learning, E-learning, Higher Education

Kata Kunci:

Blended learning, E-learning,

Pendidikan tinggi.

\section{How to cite:}

Permadi, A., \& Aditya, B. R. (2021) The Influence of Student Characteristics, Design Learning Features, and Learning Outcomes on Blended Learning Effectiveness (Case study: Higher Education in Indonesia). Edunesia: Jurnal Ilmiah Pendidikan, 2 (1): 308-318.

This is an open access article under the $C C-B Y-N C$-ND license

\begin{abstract}
The purpose of this study is to determine the effect of student characteristics, design learning features, and learning outcomes on the effectiveness of blended learning. This research was conducted at a higher education institution in the city of Bandung, Indonesia. 376 The sampling method used was purposive sampling technique, in this case involving 376 students. The data analysis method used in this study was a multiple linear regression analysis. The findings of this study indicate that the design learning features and the learning outcomes can significantly influence the implementation of blended learning, while the student characteristics do not significantly influence. It shows that to increase the effectiveness of the implementation of blended learning, we need to maximize the design learning features. Besides, factors related to student motivation and satisfaction must also be considered. Thus, the effectiveness of implementing blended learning can be increased.
\end{abstract}

Abstrak:. Tujuan penelitian ini adalah untuk mengetahui pengaruh karakteristik siswa, desain fitur pembelajaran, dan hasil belajar terhadap keefektifan blended learning. Penelitian ini dilakukan di sebuah institusi pendidikan tinggi di kota Bandung, Indonesia. pengambilan 376 sampel yang digunakan dengan teknik purposive sampling, dalam hal ini melibatkan 376 mahasiswa. Metode analisis data yang digunakan dalam penelitian ini adalah analisis regresi linier berganda. Temuan penelitian ini menunjukkan bahwa desain fitur pembelajaran dan hasil belajar berpengaruh signifikan terhadap penerapan blended learning, sedangkan karakteristik siswa tidak berpengaruh signifikan. Hal tersebut menunjukkan bahwa untuk meningkatkan keefektifan penerapan blended learning di pendidikan tinggi perlu memaksimalkan desain fitur pembelajaran. Selain itu faktor yang berhubungan dengan motivasi dan kepuasan mahasiswa juga harus diperhatikan. Dengan demikian efektivitas penerapan blended learning dapat ditingkatkan. 


\section{A. Introduction}

E-Learning is currently a learning medium based on communication information technology (ICT) that continues to develop rapidly as a supporting tool in the teaching and learning process in the education sector, especially higher education (Kintu et al., 2017; Deepak, 2017; Aditya \& Permadi, 2018). E-Learning in its time was divided into 3 generations (Pena-Rios et al., 2012). The first generation, e-learning users were still passive limited to storing teaching content on the internet with an online format. The second generation, e-learning combine access to learning, communication and student services with streaming media to create a virtual learning environment. And the third generation, a combination of learning collaboration, social, project-based learning, and a variety of learning reflexion options such as blogs, wikis, social-based learning, online simulations, open courseware all of which are accessed with a smartphone device.

Some of the advantages of e-learning include improving the quality of learning and reducing the cost of education, increasing access to learning and training, and increasing the effectiveness of education costs (Popovici \& Mironov, 2015; Morton et al., 2007). With this elearning ability, students place a better educational experience, of course, supported by strategies in transitioning to changes in learning or pedagogical styles.

The implementation of e-learning with the blended learning model becomes an advantage of higher education institutions in providing higher education services to groups of people who cannot attend education face to face, expanding access and facilitating higher education services in education and learning (Hubackova \& Semradova, 2016). It also can improve the efficiency and effectiveness of learning for students to overcome the constraints of time, distance and space (Hubackova \& Semradova, 2016).

Many higher education institutions have implemented a Learning Management System (LMS) based blended learning (Bertea, 2009; Harandi, 2015). Moodle, one of the largest open source LMSs, is used by more than $60 \%$ of all higher education providers in the world. For the continuous development of e-learning, it is necessary evaluate the analysis of the effectiveness of the implementation of the blended learning model from the perspective of first-year students based on the blended learning effectiveness model, namely student characteristics, design learning features and learning outcomes (Kintu et al., 2017). The blended learning model initially developed very quickly in the academic area of the company (Hubackova \& Semradova, 2016), because in its implementation the most useful way of using e-learning did not refer to the form of self-attendance, but was combined with classical forms of teaching or face-to-face, blended learning techniques became more widely used (Pena-Rios et al., 2012). With this advantage, the blended learning model is adopted in higher education (Paturusi et al., 2016). The blended learning model in this study uses the flipped classroom rotation model, where students rotate between online learning and learning in the classroom with a teacher. Students access online learning instructional content to do assignments and time in class is used by teachers to guide exercises, group work and remediation (Aditya et al., 2019).

The research questions are whether the student characteristics, the design learning features and learning outcomes affect for the effectiveness of blended learning?. Whether a lot of influence that on the effectiveness of blended learning either partially or simultaneously. 


\section{B. Method}

The purpose of this study was to determine the extent of the influence of student characteristics, design learning features, and student learning outcomes on the effectiveness of the implementation of blended learning.

The framework in this study is to determine whether the characteristics of students, design of learning features and learning outcomes affect the effectiveness of blended learning than partially or simultaneously with quantitative methods. there are four hypotheses to be tested in this study, which are as follows. First hypothesis: Student characteristics have a positive and significant effect on the effectiveness of the implementation of blended learning. Second hypothesis: The design learning features have a positive and significant effect on the effectiveness of the implementation of blended learning. Third hypothesis: Learning outcomes have a positive and significant effect on the effectiveness of the implementation of blended learning. Fourth hypothesis: Student characteristics, design learning features, and learning outcomes simultaneously have a positive and significant effect on the effectiveness of implementing blended learning.

In this study, data collection was carried out using a cross-sectional approach with the help of a questionnaire. The distribution of questionnaires was done online. The online questionnaire was distributed to first-year students who had attended a blended learning lecture. The sample in this study were 376 respondents. The variables in this study were designed based on the effectiveness model of blended learning (Kintu et al., 2017) consisting of nine items as shown in Table 1.

Table 1. Research Variables

\begin{tabular}{|c|c|}
\hline Variables & Items \\
\hline \multirow[t]{4}{*}{ Student characteristics } & Learning time management skills \\
\hline & Confidence for e-learning \\
\hline & $\begin{array}{l}\text { Experience in using computers and internet } \\
\text { applications }\end{array}$ \\
\hline & Family support and social environment \\
\hline \multirow[t]{3}{*}{ Design learning features } & Synchronous features (chat, forum) \\
\hline & System response \\
\hline & $\begin{array}{l}\text { Learning activity features (material, assignments, } \\
\text { quizzes) }\end{array}$ \\
\hline \multirow[t]{2}{*}{ Learning outcomes } & Motivation \\
\hline & Satisfaction \\
\hline
\end{tabular}

The questionnaire question content was designed on a Likert scale (1-5) and had been evaluated through validity and reliability tests (Guilford, 1956). The results of the validity and reliability test indicate that the questionnaire has been used to measure the effectiveness of the implementation of blended learning. As for statistical analysis, this study employed multiple regression analysis (multivariate statistical methods) (Walpole et al., 2012). This multiple regression analysis was used to determine the effect of three independent variables (student characteristics, design learning features, and learning outcomes) on one dependent variable (the effectiveness of implementing blended learning), including covering the 
simultaneous testing between the three independent variables. The maximum error limit value used is $a=5 \%$.

\section{Result and Discussion}

General description of respondents who were the objects of this study includes gender, age, and faculty as shown in Table 2.

Table 2. General description of respondents

\begin{tabular}{lccc}
\hline \multicolumn{1}{c}{ Personal Details } & Number & Percentage \\
\hline Gender & Male & 126 & $33.51 \%$ \\
\multicolumn{2}{c}{ Female } & 250 & $66.49 \%$ \\
\hline Age & $16-18$ & 56 & $14.89 \%$ \\
& $19-21$ & 320 & $85.11 \%$ \\
\multicolumn{1}{c}{$22-24$} & 0 & $0 \%$ \\
\hline Faculty & & \\
Economic and Business & 29 & $7.71 \%$ \\
Law & 40 & $10.64 \%$ \\
Cultural Science & 42 & $11.17 \%$ \\
Communciation Science & 33 & $8.78 \%$ \\
Social and Politic Science & 78 & $20.60 \%$ \\
Medice & 100 & $26.70 \%$ \\
Natural Science and Math & 39 & $10.37 \%$ \\
Agriculture & 15 & $3.99 \%$ \\
\hline
\end{tabular}

The results of the descriptive statistical analysis include min, max, mean, and standard deviation values as shown in Table 3.

Table 3. The results of the descriptive statistical

\begin{tabular}{cccccc}
\hline No & Variables & Min & Max & Mean & Std. Deviation \\
\hline 1 & Student characteristics & 1 & 5 & 4 & 0.87 \\
\hline 2 & Design learning features & 1 & 5 & 3 & 0.86 \\
\hline 3 & Learning outcomes & 1 & 5 & 3 & 0.87 \\
\hline
\end{tabular}

This stage aims to determine whether or not the instrument used in this study is valid. The r-value is a criterion in this validity test. The question items are declared valid if the $\mathrm{r}$-score is more than $\mathrm{r}$-table. The validity test results with the pearson product-moment technique can be seen in Table 4 . 
Table 4. Validity Test Results

\begin{tabular}{llcc}
\hline \multicolumn{1}{c}{ Variables } & r-score & r-table & Result \\
\hline Student characteristics & & & \\
Learning time management skills & 0.621 & 0.113 & Valid \\
$\begin{array}{l}\text { Confidence for e-learning } \\
\text { Experience in using computers and internet } \\
\text { applications }\end{array}$ & 0.686 & 0.113 & Valid \\
Family support and social environment & 0.692 & 0.113 & Valid \\
\hline $\begin{array}{l}\text { Design learning features } \\
\text { Synchronous features (chat, forum) }\end{array}$ & 0.113 & Valid \\
$\begin{array}{l}\text { System response } \\
\text { Learning activity features (material, assignments, } \\
\text { quizzes) }\end{array}$ & 0.739 & 0.113 & Valid \\
\hline $\begin{array}{l}\text { Learning outcomes } \\
\text { Motivation }\end{array}$ & & 0.113 & Valid \\
Satisfaction & 0.7113 & Valid \\
\hline
\end{tabular}

Table 4 shows that all the forming indicators of the three dimensions of the effectiveness of blended learning are valid. This stage aims to determine the level of reliability of the instruments used in this study. Cronbach alpha value is a criterion in this reliability test. If the cronbach alpha value is close to one, then it indicates the level of reliability is getting higher and can be accepted. If the cronbach alpha value is less than 0.60 then the questionnaire is declared to be unreliable or inconsistent. The reliability test results can be seen in Table 5 .

Table 5. Reliability Test Results

\begin{tabular}{ll}
\hline \multicolumn{1}{c}{ Item } & \multicolumn{1}{c}{ Value } \\
\hline Number of Questions & 9 \\
\hline The number of item variances & 6.024 \\
\hline The total value of variance & 18.062 \\
\hline Cronbach alpha value & 0.749 \\
\hline
\end{tabular}

Requirements in the multiple linear regression test must be performed multicollinearity test which part of the classic assumption test in multiple linear regression analysis the goal is to find out whether there is inter-correlation or a strong relationship between independent variables (X). A good multiple linear regression model is characterized by not happening inter-correlation between independent variables (symptoms of multicollinearity do not occur). One of the most accurate ways to detect whether or not multicollinearity symptoms are used is the tolerant method and variance inflation factor (VIF) using SPSS 22. This stage aims to determine whether there is a correlation between independent variables, in this case, the variable student characteristics, design learning features, and learning outcomes. Value of tolerance is a criterion in testing this stage. The regression model is said to be free from multicollinearity if the tolerance value 
approaches 1 and the VIF value is less than 10. The summary of the multicollinearity test results can be seen in Table 6 .

Table 6. Multicollinearity Test Results

\begin{tabular}{ccc}
\hline Variables & Tolerant & VIF \\
\hline Student characteristics & 0.766 & 1.305 \\
\hline Design learning features & 0.683 & 1.305 \\
\hline Learning outcomes & 0.708 & 1.412 \\
\hline
\end{tabular}

Table 6 shows that the tolerance value and VIF of student characteristics, design learning features, and learning outcomes are close to 1 and the value of VIF is smaller than 10 so it can be ascertained that there is no multicollinearity. So by looking at the value of tolerance and VIF, the conclusion is that there are no symptoms of multicollinearity in the linear regression model in this study. The heteroscedasticity test is part of a classic assumption test in the regression model. One of the requirements that must be met in a good regression model is that there are no symptoms of heteroscedasticity. Meanwhile, the occurrence of heteroscedasticity symptoms will result in multiple regression models the results of the analysis become less accurate. This stage aims to determine whether there are differences in residual variance between observations. Scatter plot graph between the value of the dependent variable and the residual value becomes a benchmark of testing. If the scatter plot graph forms a regular pattern, it can be said to occur heteroscedasticity, and vice versa if the points are above and below the number 0 on the $Y$-axis then it can be said there is no heteroscedasticity. The heteroscedasticity test results can be seen in Figure 1.

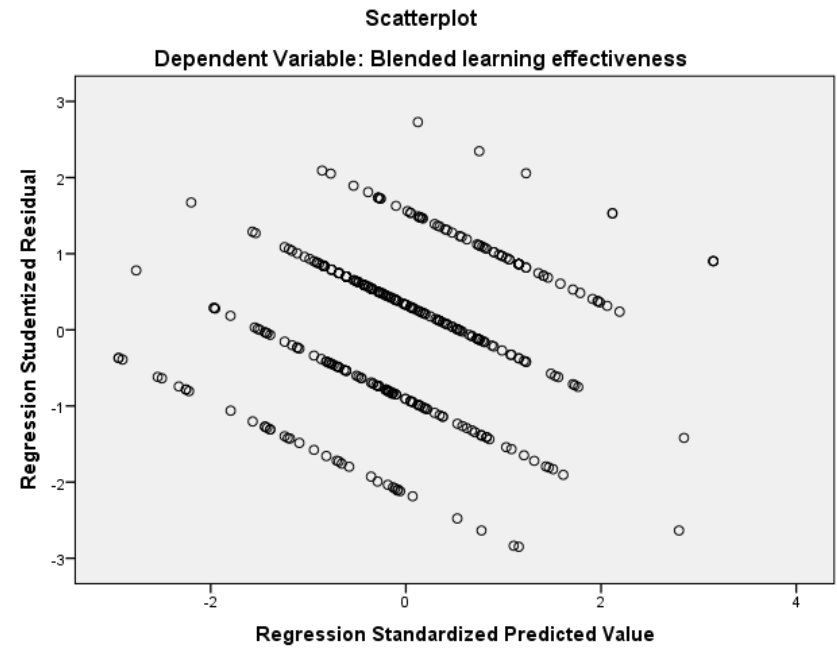

Figure 1. Scatter Plot.

Figure 2 shows that the points are above and below the number 0 on the Y-axis, the points do not gather just above or below it, so it can be said that there is no heteroscedasticity. This stage aims to determine whether all the variables are distributed or also mentioned normal residual values or not. Some provisions for the normal probability plot are as follows data or points spread around and follow the direction of the diagonal 
line. Otherwise, if the points move away from the diagonal line then the data distribution is not normally distributed. The normal probability plot graph becomes the test criteria in this stage. The normality test results can be seen in Figure 2.

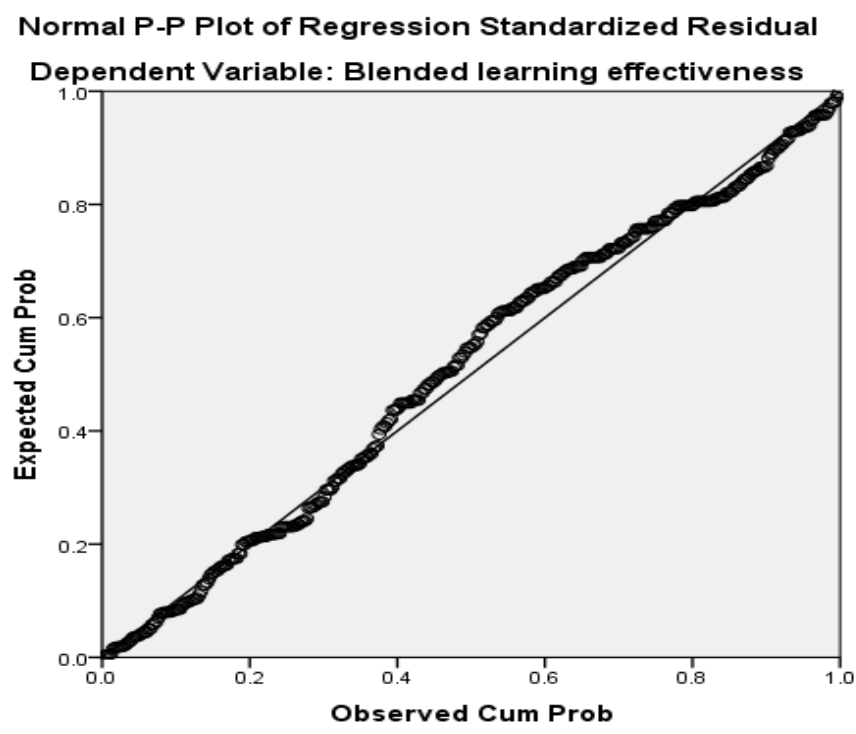

Figure 2. Normal Probability Plot.

Judging from the points in Figure 3, the data or points spread around and following the direction of the diagonal line can be concluded that the overall distribution of the distributed data variable is normal.

\section{T-test}

This stage aims to find out how the relationship between each independent variable (student characteristic, design learning features, and learning outcomes) with the dependent variable (the effectiveness of implementing blended learning). The $\mathrm{p}$-value becomes the test criteria in this stage. If the p-value is less than 0.05 , it can be concluded that the independent variable has a partially significant effect on the dependent variable. The results of the t-test can be seen in Table 7.

Table 7. Partial Test Results (t-test)

\begin{tabular}{cc}
\hline Variables & p-value (significance) \\
\hline Student characteristics & 0.083 \\
\hline Design learning features & 0.000 \\
\hline Learning outcomes & 0.000 \\
\hline
\end{tabular}

Table 7 shows that the p-value for the design learning features variable and the learning outcomes variable are 0.00 and 0.00 (less than 0.05 ). This shows that the findings of this study confirm that the design learning features and the learning outcomes significantly influence the effectiveness of the implementation of blended learning. As with the p-value for student characteristics greater than $0.05(p$-value $=0.083)$, it can be interpreted that the 
student characteristics do not significantly influence the effectiveness of the implementation of blended learning.

\section{F-test}

This stage aims to find out how the relationship of independent variables (student characteristics, design learning features, and learning outcomes) simultaneously against the dependent variable (the effectiveness of implementing blended learning). The $p$-value becomes the test criteria in this stage. If the p-value is less than 0.05 , it can be concluded that all independent variables simultaneously influence the dependent variable. The F-test results can be seen in Table 8 .

Table 8. F-test (Anova)

\begin{tabular}{cllllc}
\hline & df & SS & MS & F & Significance F \\
\hline Regression & 3 & 90.489 & 30.163 & 45.924 & 0.000 \\
Residual & 373 & 244.986 & 0.657 & & \\
Total & 376 & 335.475 & & & \\
\hline
\end{tabular}

Table 8 shows that the significant $F$ value is 0,000 (less than 0.05 ). Thus it can be seen that there is an influence jointly or simultaneously between student characteristics, design learning features, and learning outcomes on the effective implementation of blended learning.

\section{Coefficient of Determination}

This stage aims to determine whether changes in the independent variable (student characteristics, design learning features, and learning outcomes) will be followed by the dependent variable (the effective implementation of blended learning). The value of $R$ square (R2) shows the proportion of the independent variables in influencing the dependent variable. The coefficient of determination in this study is 0.270 . This means that student characteristics, design learning features, and learning outcomes affect the effectiveness of the implementation of blended learning by $27 \%$. Conversely, $73 \%$ implies that in addition to the three variables, other things affect the effectiveness of the implementation of blended learning.

\section{Multiple Linear Regression Analysis}

This stage aims to find out how much the relationship of student characteristic, design learning features, and learning outcomes to the effective implementation of blended learning. The resulting regression model can be seen in equation 1 .

Equation 1. $Y=0.037 X_{1}+0.162 X_{2}+0.172 X_{3}$

A value of 0.037 on the student characteristics variable (X1) is positive so it can be said that the better the characteristics of students, the better the effective implementation of blended learning. The value of 0.162 on the design learning features variable (X2) is positive so it can be said that the better the design learning features, the better the effective 
implementation of blended learning. The value of 0.172 on the learning outcomes variable (X3) is positive so it can be said that the better the learning outcomes, the better the effective implementation of blended learning.

\section{Discussion}

In this study we investigated four variabels they are the potential characteristics of students, design learning features and learning outcomes both partially and simultaneously on the effectiveness of blended learning. That generate four hypotheses. We used a sample of 376 students in a course program at a higher education institution in Indonesia. First Hypothesis there is no evidence to show that student characteristics have a positive and significant effect on the effectiveness of blended learning. This can be seen from the significance value ( $\mathrm{p}$-value) for the variable student characteristics of 0.083 (greater than 0.05 ) and a regression coefficient of 0.037 . Thus it can be concluded that the student characteristics have a positive effect, but it does not significantly affect the effective implementation of blended learning.

Second hypothesis there is evidence to suggest that the design learning features have a positive and significant effect on the effective implementation of blended learning. This can be seen from the significance value ( $p$-value) for the design learning features variable of 0,000 (smaller than 0.05) and a regression coefficient value of 0.162 . Thus the effective implementation of blended learning is influenced by the design learning features. So the better the design learning features, the better the effective implementation of blended learning.

Third hypothesis there is evidence to show that learning outcomes have a positive and significant effect on the effective implementation of blended learning. This can be seen from the significance value ( $\mathrm{p}$-value) for the learning outcomes variable of 0,000 (smaller than 0.05 ) and a regression coefficient value of 0.172 . Thus it can be concluded that the effective implementation of blended learning is influenced by student learning outcomes. So the higher the student's learning outcomes, the better the effective implementation of blended learning.

Fourth hypothesis the variable Student characteristics, design learning features and learning outcomes simultaneously significantly influence the effective implementation of blended learning. This can be seen from the significance value ( $\mathrm{p}$-value) for the simultaneous test variable (F-test) of 0,000 (less than 0.05 ). Thus, together, the effective implementation of blended learning is influenced by student characteristics, design learning features, and learning outcomes.

By analyzing the influence of student characteristics, design learning features, and learning outcomes on the effectiveness of blended learning, this study contributes to the field of blended learning specifically and the field of education in general. This research empirically examines what aspects affect students in the implementation of blended learning based on the perception of first-year students in higher education in Indonesia.

The results of this study indicate that design learning features and learning outcomes have a significant influence on the effectiveness of blended learning. This is consistent with some of the results of previous studies, such as the results of research conducted by Kintu et al (2017) and Deepak (2017) which show that the design of efficient LMS features influences on increasing the effectiveness of online learning. Besides, other findings of this study also support the results of research conducted by Harandi (2015), Parahoo et al (2016) and Kolb (2014) which shows that student motivation and satisfaction, in general, will affect 
the effectiveness of the implementation of learning in a virtual environment. Thus the design learning features and learning outcomes become important things to be considered by the organizer of blended learning.

Although the results of this study indicate that the student characteristics do not significantly affect the effectiveness of blended learning, this variable still has influence and must still be considered by higher education institutions. This is because it is related to the process of adopting the technology. According to Zang et al (2018), the success of the process of adopting the technology will be influenced by the characteristics of students, in this case covering the social and demographic conditions of students.

Overall, the results of this study are following the theory of the seven basic principles for successful virtual classroom proposed by Clark \& Kwinn (2007). These principles emphasize that successful learning in a virtual environment (online learning) will depend on the extent to which teachers develop an effective virtual learning environment, ranging from syllabus planning, use of the media, to an emphasis on the motivation and satisfaction of teaching participants.

\section{Conclusion}

Based on the research findings, the multiple linear regression equation will be obtained as follows $\mathrm{Y}=0.037 \mathrm{X} 1+0.162 \mathrm{X} 2+0.172 \mathrm{X} 3$.

Based on multiple linear regression analysis, it can be seen that the most influential against the effective implementation of blended learning is the design learning features and learning outcomes variables with regression coefficient values of $16.20 \%$ and $17.20 \%$, respectively. While the student characteristics variable has a positive but not significant effect with a regression coefficient of $3.7 \%$.

In the assessment of hypotheses using the F test (together or simultaneously), it can be explained that the three variables namely the student characteristics variable, the design learning features variable, and the learning outcomes variable jointly affect the effective implementation of blended learning.

The resulting coefficient of determination is 0.27 . This means that 27 per cent of the change in the effective implementation of blended learning can be explained by changes in student characteristic variables, the design learning features, and learning outcomes. While 73 per cent of students are explained by other variables not included in this study.

\section{References}

Aditya, B. R. \& Permadi, A. (2018). Implementation of UTAT Model to Understand the Use of Virtual Classroom Principle in Higher Education. Journal of Physics: Conference Series, $81(1)$.

Aditya, B. R., Nurhas, I., \& Pawlowski, J. 2019. Towards Successful Implementation of a Virtual Classroom for Vocational Higher Education in Indonesia. Learning Technology for Education Challenges (pp.151-161) Springer, Cham.

Deepak, K. C. (2017). Evaluation of Moodle Features at Kajaani University of Applied SciencesCase Study (pp.121-128) Procedia Computer Science. 
Harandi, R. S. (2015). Effects of e-learning on students' motivation. International Conference on Leadership E Technology (pp.423-430) Elsevier Ltd.

Hubackova, S., \& Semradova, I. (2016). Evaluation of Blended learning. Procedia - Social and Behavioral Sciences.pp (551-557) Elsevier Ltd.

Kintu, M J., Zhu, C., \& Kagambe, E. (2017). Blended Learning Effectiveness: The Relationship Between Student Characteristics, Design Features and Outcomes. International Journal of Educational Technology in Higher Education, 14, 1-20

Kolb, D.A. (2014). Experiential Learning: Experience as the Source of Learning and Development. Prentice Hall, Englewood Hills.

Moodle (n.d). The platform of choice for higher education institutions worldwide from https:/ / moodle.com/solutions/higher-education/

Parahoo, S. K., Santally, M. I., Rajabalee, Y., \& Harvey, H. L. (2016). Designing a predictive model of student satisfaction in online learning. Journal of Marketing for Higher Education, 26(1), 1-19.

Paturusi, S., Usagawa, T., \& Lumenta. S, (2016). A Study of Students' Satisfaction Toward Blended learning Implementation in Higher Education Institution in Indonesia. International Conference on Information, Communication Technology and System IEEE.

Pena-Rios, A., Callaghan, V., Gardner, M., \& Alhaddad, A. J. (2012). Toward the next generation of learning environments: An interReality learning portal and model. International Conference on Intelligent Environments IEEE.

Popovici, A \& Mironov, C. (2015). Student's perception on using eLearning technologies. Procedia - Social and Behavioral Sciences (pp.1514-1519) Elsevier Ltd.

Walpole, R. E., Myers, R. H., Myers, S. L., \& Ye, K. (2012). Probability E statistics for engineers $\mathcal{E}$ scientists. Boston: Prentice Hall.

Zhang, G., Dang, M., Amer, B., \& Trainor, K. (2018). Who Favor Blended Learning More: Men or Women? An Explorative Study on Gender Differences. PACIS AIS Electronic Library. 